Research paper

\title{
A Middle Devonian Callixylon (Archaeopteridales) from Ronquières, Belgium
}

\author{
Luc Cornet $^{\text {a }}$, Philippe Gerrienne ${ }^{\mathrm{a}, *}$, Brigitte Meyer-Berthaud ${ }^{\mathrm{b}, \mathrm{c}}$, Cyrille Prestianni ${ }^{\mathrm{d}}$ \\ a Paléobiogéologie, Paléobotanique et Paléopalynologie, Département de Géologie, B18, Université de Liège, Sart Tilman, Liège 1, Belgium \\ b Université Montpellier 2, UMR AMAP, Montpellier, F-34000, France \\ c CNRS, UMR AMAP, Montpellier, F-34000, France \\ ${ }^{d}$ RBINS, Rue Vautier, 29, B-1000 Bruxelles, Belgium
}

\section{A R T I C L E I N F O}

Article history:

Received 6 March 2012

Received in revised form 3 July 2012

Accepted 6 July 2012

Available online 16 July 2012

\section{Keywords:}

archaeopteridalean lignophyte

Callixylon

Givetian

pyrite permineralization

Ronquières

tree

\begin{abstract}
A B S T R A C T
A permineralized Callixylon trunk is reported from Ronquières, a mid to late Givetian (Middle Devonian) locality from Belgium. The specimen consists of an $80 \mathrm{~cm}$ long trunk adpression whose central area is preserved as a pyrite permineralization. The pyritized area is composed of a eustele surrounded by secondary xylem. Tracheids show radially aligned groups of pits separated by unpitted regions on the radial walls of tracheids. The specimen belongs to a group of species characterized by a predominance of uniseriate rays and the lack of ray tracheids. This Callixylon specimen is one of the earliest representatives of the genus. It coexists at the locality with large cladoxylopsids and provides direct evidence that the tree habit had evolved in the archaeopteridalean progymnosperms by the Givetian.
\end{abstract}

(c) 2012 Elsevier B.V. All rights reserved.

\section{Introduction}

The widely distributed archaeopteridalean progymnosperms were prominent components of the terrestrial ecosystems during the Late Devonian (Meyer-Berthaud et al., 1999); their remains have been abundantly documented. The order Archaeopteridales includes the genera Actinopodium Høeg, Actinoxylon Matten, Archaeopteris Stur, Callixylon Zalessky, Eddya Beck, Siderella Read and Svalbardia Høeg (Beck and Wight, 1988; Taylor et al., 2009), with Archaeopteris and Callixylon being by far the best known taxa. The genus name Callixylon Zalessky (1911) is applied to permineralized archaeopteridalean stem, branch and root fragments whose secondary xylem includes tracheids with radially aligned groups of small circular bordered pits separated by unpitted regions (Beck, 1960). The primary vascular system of Callixylon stems and branches is eustelic; it is protostelic in roots (Beck and Wight, 1988). The first diagnosis of the genus was published by Lemoigne et al. (1983). The name Archaeopteris Stur (1875) (see Wang, 2011 for the taxonomical background of the genus) applies to lateral branching systems preserved as adpressions, that superficially resemble the compound fronds of ferns. Beck (1960) demonstrated the connection between a specimen of Callixylon zalesskyi Arnold and frond-like branches of Archaeopteris macilenta Lesquereux from the Late Devonian of New York. Despite this evidence, Callixylon and

\footnotetext{
* Corresponding author.

E-mail address: P.Gerrienne@ulg.ac.be (P. Gerrienne).
}

Archaeopteris are kept separated. They correspond to fossils with different taphonomical histories, which preserve different sets of traits. Within the Archaeopteridales, Callixylon is the only genus corresponding to roots, stems, and proximal branches. In contrast, several genera have been erected for leafy branches in relation to the morphology and bi/ tri-dimensionality of their units (e.g. Archaeopteris, Svalbardia, Actinoxylon); their congenericity has been questioned but never resolved (Beck and Wight, 1988). It is therefore possible that Callixylon does not strictly overlap with Archaeopteris.

We report here the discovery of an $80 \mathrm{~cm}$ long Callixylon specimen collected in 2005 at a newly discovered fossiliferous outcrop located along the "plan incliné de Ronquières" in Belgium. The present paper is a preliminary description of the primary and secondary xylem of the plant; the establishment of the detailed phyllotaxy of the specimen is currently underway at Liège University.

\section{Locality and source strata}

The locality that yielded the specimen of Callixylon studied here is some $300 \mathrm{~m}$ northeast from the "Ronquières, tour du plan incliné (tête amont)" locality reported by Stockmans in 1968 (fig. 1). The flora collected at Stockmans' locality is the most diverse Middle Devonian plant assemblage from Belgium (Berry, 2008). It includes zosterophyllopsids, lycopsids, cladoxylopsids, aneurophytalean and archaeopteridalean progymnosperms, the proto-ovule Runcaria Stockmans, as well as various incertae sedis taxa (Stockmans, 1968; Fairon-Demaret, 1981; Gerrienne et al., 2004; Scheckler et al., 2006; 


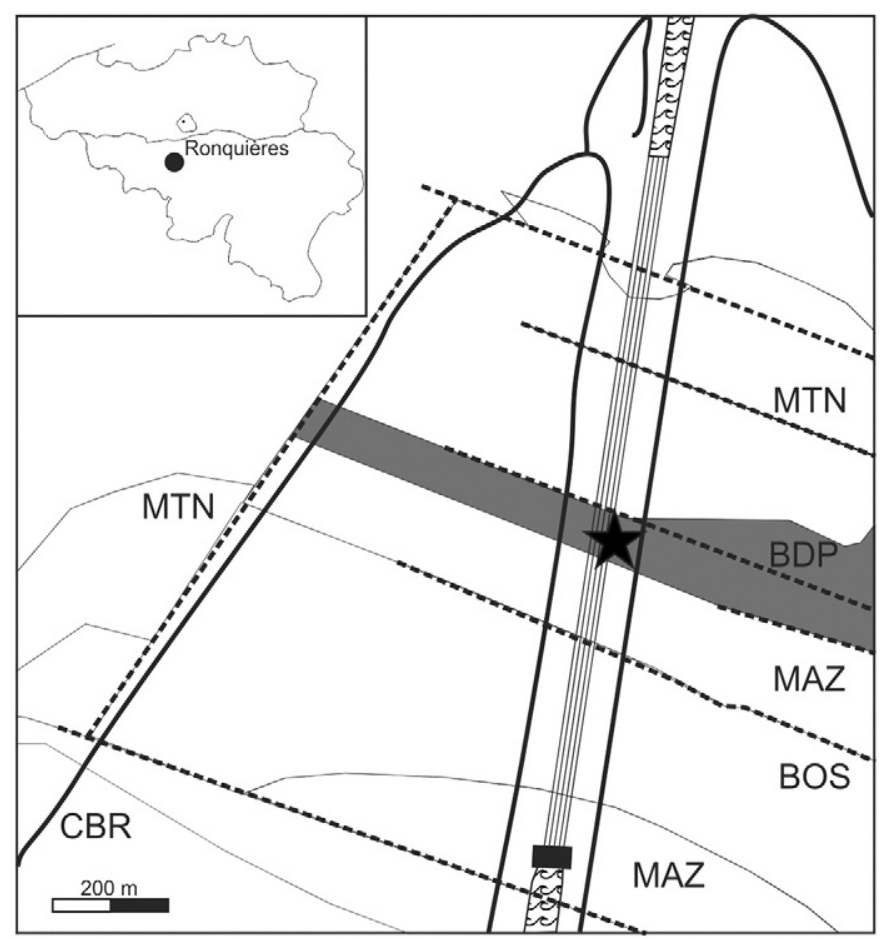

Fig. 1. Simplified geological map of the Plan Incliné area, showing the approximate position of the fossiliferous locality (star). Parallel thin full lines: railway of the "plan incline"; other thin full lines: limits of the Formation Members; thick full lines: roads; dotted line: faults. BDP = Bois du Planti Member of the Bois de Bordeaux Formation (mid Givetian); BOS = Bossière Member of the Bovesse Formation (early Frasnian); $\mathrm{CBR}=$ Combreuil Member of the Bovesse Formation (early Frasnian); MAZ = Mazy Member of the Bois de Bordeaux Formation (late Givetian); MTN = Les Mautiennes Member of the Bois de Bordeaux Formation (early Givetian) (Hennebert and Eggermont, 2002).

Modified from Hennebert and Eggermont (2002).

Gerrienne and Meyer-Berthaud, 2007). Stockmans' flora is in need of an in-depth revision.

The newly discovered fossiliferous outcrop is located along the "plan incliné" (fig. 1). It belongs to the Bois du Planti Member of the Bois de Bordeaux Formation (Bultynck et al., 1991) and mainly consists of alternating grey fossiliferous shale and sandstone. In addition to Callixylon, the new outcrop has yielded compression fossils representing cladoxylopsid trunks, pyritized remains of woody cladoxylopsids and of stenokolean axes of Crossia Beck and Stein, and a large number of as yet unidentified compressions (Gerrienne and Meyer-Berthaud, 2006, 2010; work in progress at Liège University).

The plant fossils which were deposited in a floodplain environment are allochthonous in the two localities.

At both localities, the miospore assemblage includes, among other species, Acinosporites lindlarensis Riegel (1968), Ancyrospora ancyrea var. ancyrea Richardson (1962), Grandispora velata (Eisenack) Playford (1971), Rhabdosporites langii (Eisenack) Richardson, 1960, Verrucosisporites premnus (Richardson) Richardson (1965), Geminospora lemurata Balme, 1962, Chelinospora concinna Allen (1965), Samarisporites triangulatus Allen (1965) and Aneurospora greggsii (McGregor) Streel (in Becker et al., 1974). On this basis, both localities have been attributed a mid to late Givetian age (TA Oppel Zone; Gerrienne et al., 2004; Ville de Goyet et al., 2007).

\section{Material and methods}

The specimen ULg- 13560 consists of an $80 \mathrm{~cm}$ long and $12-15 \mathrm{~cm}$ wide laterally compressed axis, with a $5.5 \mathrm{~cm} \times 1.8 \mathrm{~cm}$ wide central area preserved as a pyrite permineralization. Several bumps, which may represent branch traces, are visible on the surface of the specimen.
This part has been cut into 8 segments, each about $10 \mathrm{~cm}$ in length. All segments have been studied either by the thin section and wafering method (78 slides) or by the acetate peel technique (approximately 60 peels) after having been etched by nitric acid (Matten, 1973; Galtier and Phillips, 1999; Hass and Rowe, 1999; Kenrick, 1999).

The nature of this specimen, branch or trunk, is difficult to ascertain. On the basis of its width $(12-15 \mathrm{~cm})$ and lack of conicity, we presume that it represents a portion of trunk. The compression of the specimen suggests that it was fossilized parallel to the bedding plane. The primary tissues and secondary xylem of one face are badly preserved (Plate I, 1).

\section{Results}

\subsection{Transverse section}

The permineralized central area of the specimen consists of a eustele surrounded by an incompletely and asymmetrically preserved zone of secondary xylem composed of tracheids and rays only (Plate I, 1).

The preserved primary tissues include a parenchymatous pith surrounded by a ring of discrete primary vascular bundles. The specimen has been flattened and the pith is elliptical (Plate I, 1, 2). Its major diameter ranges from 25 to $29 \mathrm{~mm}$, the minor diameter from 4 to $7 \mathrm{~mm}$. This variation is a taphonomic feature, not related to the proximal versus distal position of the section. The cells in the central portion of the pith are badly preserved. Scattered thick-walled cells, some showing black contents, may represent sclereids (Plate I, 2, 3). They are present in all parts of the pith but occur predominantly in the 1-2 mm wide outermost part (Plate I, 2).

Twenty-five primary vascular bundles are visible. The original number of primary bundles was probably around 30. Maturation of the primary xylem is mesarch (Plate I, 2, 4). The protoxylem strand includes thin-walled, possibly parenchymatous, cells (Plate I, 4). Most vascular bundles are not in contact with the inner edge of the secondary xylem (Plate I, 2). Additional minute primary xylem strands are possibly present between the more conspicuous ones (Plate I, 5, arrows). Sclereids may be present around the primary vascular bundles (Plate I, 2). The tracheids of primary xylem are circular to elliptical in section with a major diameter ranging from 6 to $77 \mu \mathrm{m}$ and a minor diameter ranging from 7 to $60 \mu \mathrm{m}$ (Plate I, 2).

The thickness of the secondary xylem varies from 4 to $8 \mathrm{~mm}$ on one side of the specimen, from 1 to $3 \mathrm{~mm}$ on the other side. There is no significant change in the thickness of the preserved part of the wood along the specimen. Tracheids of the secondary xylem are mostly rectangular in section (Plate I, 5). Their radial diameter ranges from 22 to $44 \mu \mathrm{m}(\mathrm{N}=50$; mean: $31 \mu \mathrm{m}$; standard deviation: $5 \mu \mathrm{m})$ and their tangential dimension from 13 to $46 \mu \mathrm{m}(\mathrm{N}=50$; mean: $25 \mu \mathrm{m}$; standard deviation: $6 \mu \mathrm{m}$ ). The thickness of the tracheid walls is $3 \mu \mathrm{m}$ in average. Rays are narrow. They enlarge significantly in the innermost part of the wood. There, groups of 2-7 rows of tracheids are separated by enlarged rays in connection with the pith (Plate I, 1 ; but see also these inflated rays in longitudinal section in Plate II, 1, 4).

\subsection{Longitudinal tangential section}

Enlarged rays in the portion of secondary xylem adjacent to the pith range from 326 to $1789 \mu \mathrm{m}$ in height (Plate II, 1) and 60 to $295 \mu \mathrm{m}$ in width. In the central part of the secondary xylem there are 10 to 16 rays per tangential $\mathrm{mm}$. There, rays are uniseriate and fusiform, rarely biseriate in part (Plate II, 3) and they are composed of 1 to 13 cells in height, mostly 1 to 7 cells ( $N=10$; mean: 12 rays; standard deviation: 2 rays). Ray height (Plate II, 2) varies from 17 to $511 \mu \mathrm{m}(\mathrm{N}=50$; mean: $223 \mu \mathrm{m}$; standard deviation: $142 \mu \mathrm{m})$; ray width varies from 12 to $33 \mu \mathrm{m}(\mathrm{N}=50$; mean: $19 \mu \mathrm{m}$; standard deviation: $5 \mu \mathrm{m}$ ). Bordered pits similar in size and arrangement to those 


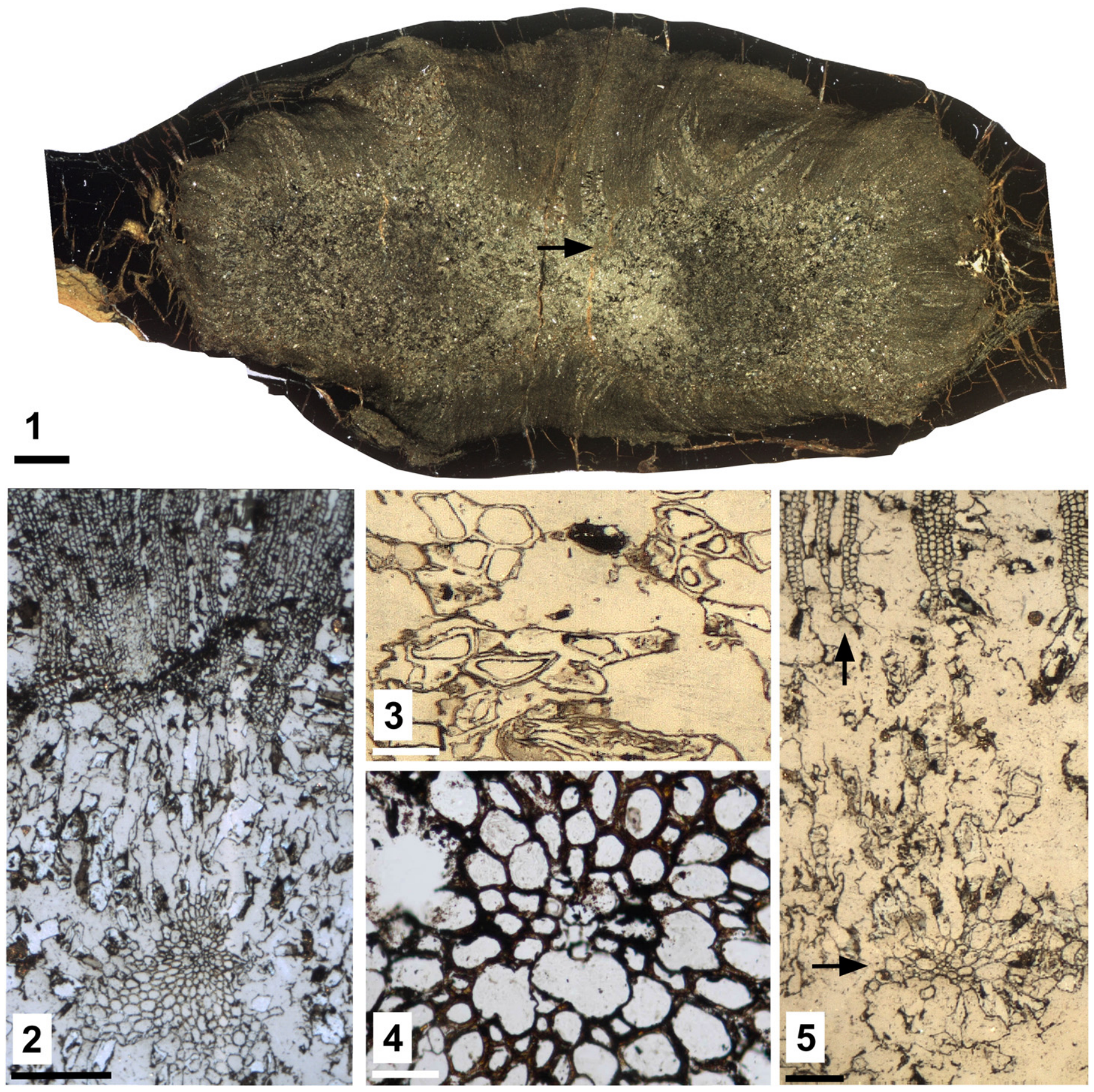

Plate I. Callixylon sp. from Ronquières (Belgium); mid to late Givetian (Middle Devonian). Specimen ULg-13560. Transverse sections, except for fig. 4.

1. Gross view showing, from inside to outside: the pith, the primary vascular bundles, the incomplete and asymmetrical zone of secondary xylem. Arrow points at a primary xylem bundle. Scale bar $=2 \mathrm{~mm}$.

Primary vascular bundle detached from the inner edge of the secondary xylem. Note cells showing black contents, possibly representing sclereids. Scale bar $=500 \mu \mathrm{m}$.

3. Detail of a primary vascular bundle. Maturation of the primary xylem is mesarch. The protoxylem strand includes thin-walled, possibly parenchymatous, cells. Scale bar $=50 \mu \mathrm{m}$

4. Sclereids in tangential section. Scale bar $=50 \mu \mathrm{m}$.
5. Possible additional minute primary xylem strands (arrows). Scale bar $=200 \mu \mathrm{m}$.

on the radial walls of the tracheids seem present on the tangential walls in the innermost part of the wood (Plate II, 4). It is possible that this observation is artefactual and actually corresponds to the pitting on radial walls of distorted tracheids. Ray cells are parenchymatous. Sclereids are present in the pith (Plate I, 3).

\subsection{Longitudinal radial section}

The bordered pits on the radial walls of tracheids are multiseriate (Plate II, 5) and closely adpressed against each other. Their outline is elliptical to circular (Plate II, 5). Their diameter ranges from 7 to 

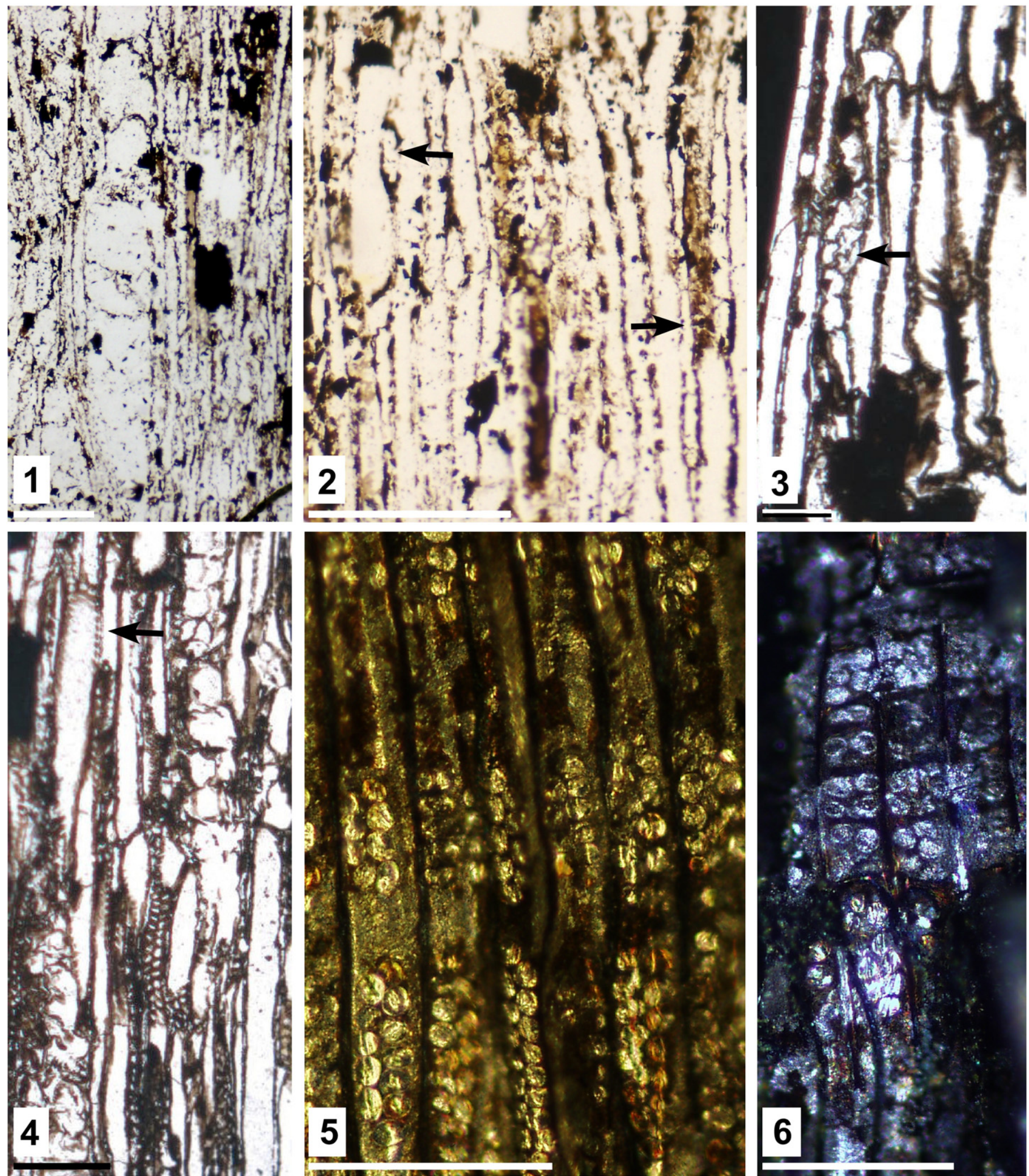

Plate II. Callixylon sp. from Ronquières (Belgium); mid to late Givetian (Middle Devonian). Specimen ULg-13560. Longitudinal sections.

Tangential section. Enlarged ray in the secondary xylem adjacent to the pith. Scale bar $=200 \mu \mathrm{m}$.

Tangential view showing the rays. Arrows indicate two rays of different heights. Scale bar $=200 \mu \mathrm{m}$.

Tangential view showing a partially biseriate ray (arrow). Scale bar $=50 \mu \mathrm{m}$.

Tangential view showing tangential pitting of the tracheids. The arrow indicates a tracheid with pits on the radial and tangential walls. Scale bar $=100 \mu \mathrm{m}$.

Radial view showing the bands of pits separated by unpitted areas. Scale bar $=100 \mu \mathrm{m}$

Radial view showing cross-fields with $4-5$ half-bordered circular pit pairs. Scale bar $=100 \mu \mathrm{m}$. 
$16 \mu \mathrm{m}(\mathrm{N}=100$; mean: $11 \mu \mathrm{m}$; standard deviation: $1 \mu \mathrm{m})$. The pit aperture is elliptical and tilted $45^{\circ}$.

The radial walls of tracheids characteristically show radial bands of grouped pits (Plate II, 5). Each group contains 6 to 24 pits $(\mathrm{N}=$ 50; mean: 14 pits; standard deviation: 5 pits) and includes most generally alternating biseriate or triseriate rows (Plate II, 5). The height of the pit groups varies from 43 to $134 \mu \mathrm{m}(\mathrm{N}=50$; mean: $77 \mu \mathrm{m}$; standard deviation: $22 \mu \mathrm{m})$; their width varies from 13 to $39 \mu \mathrm{m}(\mathrm{N}=50$; mean: $77 \mu \mathrm{m}$; standard deviation: $22 \mu \mathrm{m}$ ). The bands of pits are separated by unpitted areas (Plate II, 5) whose height varies from 10 to $77 \mu \mathrm{m}$ ( $\mathrm{N}=50$; mean: $24 \mu \mathrm{m}$; standard deviation: $6 \mu \mathrm{m})$. At places, the arrangement of pits in groups is not obvious; this character is probably variable in the specimen.

The rays are composed of rectangular parenchyma cells (Plate II, 6 ). The size of the few observed cross-fields is variable. Their height varies from 21 to $44 \mu \mathrm{m}$ and their width from 20 to $47 \mu \mathrm{m}$. Half-bordered circular pit pairs are present in the cross-fields. Their number varies from 3 to 9 pits. Their diameter varies from $6 \mu \mathrm{m}$ to $14 \mu \mathrm{m}$. The aperture of the pit is circular to elliptical; in this case, it is either tilted $45^{\circ}$ or horizontal. Ray tracheids are absent.

\section{Discussion}

The presence of radially aligned groups of pits is the main diagnostic feature for identifying the genus Callixylon (Arnold, 1929; Orlova and Jurina, 2011). It should nevertheless be noted that Scheckler and Banks (1971) illustrated a radial section of the secondary xylem of Triloboxylon hallii (Arnold) Scheckler and Banks [renamed Triloboxylon arnoldii by Matten (1974)], with grouped pitting similar to that of Callixylon. Stein and Beck (1983), in their revision of the species, found in only one instance a potential grouped pitting, and suggested that this apparently grouped pitting was rather due to the presence of a short vascular ray. Thus, the use of the character "presence of radially aligned group of pits" for the generic identification of Callixylon appears justified. The specimen from Ronquières clearly exhibits grouped pitting on the radial walls of the secondary xylem tracheids; consequently, the specimen is attributed to the genus Callixylon. Another character of the genus is the presence of mesarch primary vascular bundles at the periphery of the pith, in contact or not with the secondary xylem (Beck, 1953; Lemoigne et al., 1983). This character is also present in the Ronquières specimen.

Species of Callixylon are essentially distinguished from each other by ray characters, such as ray seriation and the presence/absence of ray tracheids (Beck, 1981; Lemoigne et al., 1983; Orlova and Jurina, 2011). In Table 1, we have listed characters of the ray tissue for the species of Callixylon recognized as valid by Lemoigne et al. (1983) and Orlova and Jurina (2011). The Ronquières specimen is characterized by (i) a majority of short uniseriate rays and rare partly biseriate rays, and (ii) the lack of horizontal ray tracheids. It is consistent with the "trifilievii group" of Orlova and Jurina (2011) that spans the entire Upper Devonian and includes Callixylon trifilievii and its "junior synonyms" (Callixylon marshii, Callixylon henkei, Callixylon velinense, Callixylon clevelandensis, Callixylon huronensis) as well as Callixylon brownii and Callixylon whiteanum (Table 1). Lemoigne et al. (1983) circumscribe C. trifilievii and its possible synonyms (Callixylon zalesskyi, C. whiteanum and C. velinense) to specimens that have uniseriate rays only and that possess ray tracheids, which thus differ from the Ronquières specimen. The occurrence of ray tracheids in the type material of $C$. trifilievii and that of $C$. whiteanum however is contested by Beck and Wight (1988). In addition, rays in C. whiteanum can be partly, or entirely biseriate, which adds confusion to the concept of $C$. trifilievii as defined by Lemoigne et al. (1983). The Ronquières specimen has only its innermost, juvenile part of the wood preserved and does not show the whole range of variation originally presented by its wood. In view of these uncertainties, we are reluctant to suggest any specific identification for this specimen and we call it Callixylon sp. We, however, suspect that it belonged to a species included in the "trifilievii group" of Orlova and Jurina (2011).

Most Callixylon sp. are of Late Devonian age (Lemoigne et al., 1983 and references herein). Before this work, direct evidence of the occurrence of Callixylon in Givetian plant deposits was few. A 5-7 cm wide specimen of Callixylon velinense (Marcelle, 1953) was collected from Sart-Dame-Avelines, a late Givetian locality from Belgium (Stockmans, 1968; Bultynck et al., 1991). Callixylon marshii (Hylander, 1922, cited in Arnold, 1930) is based on a small piece of badly preserved wood collected from the Eighteen Mile Creek, Erie County, New York State. The

Table 1

Ray characters for the Callixylon species recognized as valid by Lemoigne et al. (1983) and Orlova and Jurina (2011).

\begin{tabular}{|c|c|c|c|c|c|c|}
\hline $\begin{array}{l}\text { Valid species according } \\
\text { to } 12\end{array}$ & $\begin{array}{l}\text { Valid species according } \\
\text { to } 15\end{array}$ & $\begin{array}{l}\text { Synonymy according } \\
\text { to } 12\end{array}$ & $\begin{array}{l}\text { Synonymy according } \\
\text { to } 15\end{array}$ & Ray seriation & $\begin{array}{l}\text { Presence of ray } \\
\text { tracheids }\end{array}$ & Age according to 15 \\
\hline C. trifilievii (16) & C. trifilievii (16) & $\begin{array}{l}\text { C. velinense (14) } \\
\text { C. zalesskyi (1) } \\
\text { C. whiteanum (2) }\end{array}$ & $\begin{array}{l}\text { C. huronensis (6) } \\
\text { C. henkei (10) } \\
\text { C. clevelandensis (5) } \\
\text { C. marshii (9) } \\
\text { C. velinense (14) }\end{array}$ & Strictly uniseriate & $\begin{array}{l}\text { Present (12) } \\
\text { Absent (15) }\end{array}$ & Frasnian-Famennian \\
\hline C. henkei (10) & & & C. trifilievii (16) & Strictly uniseriate & Absent & Famennian \\
\hline C. petryi (3) & C. petryi (3) & & & Strictly uniseriate & Present & Frasnian \\
\hline \multirow[t]{2}{*}{ C. brownii (8) } & C. brownii (8) & & & $\begin{array}{l}\text { Uniseriate ( } 80 \%) \text {, occasionally } \\
\text { locally biseriate }\end{array}$ & Absent & $\begin{array}{l}\text { Upper Devonian-Lower } \\
\text { Mississippian }\end{array}$ \\
\hline & C. whiteanum (2) & C. trifilievii (16) & & $\begin{array}{l}\text { Uniseriate, rarely totally biseriate, } \\
\text { frequently biseriate in part }\end{array}$ & $\begin{array}{l}\text { Rare or } \\
\text { absent (2) } \\
\text { No (15) } \\
\text { Rare (12) }\end{array}$ & $\begin{array}{l}\text { Upper Devonian-Lower } \\
\text { Mississippian }\end{array}$ \\
\hline \multirow{2}{*}{ C. bristolense (1) } & C. erianum (1) & & C. bristolense (1) & $\begin{array}{l}\text { Uniseriate, occasionally biseriate } \\
\text { Uniseriate except the broad ones }\end{array}$ & $\begin{array}{l}\text { Present } \\
\text { Present }\end{array}$ & $\begin{array}{l}\text { Frasnian-Famennian } \\
\text { Frasnian }\end{array}$ \\
\hline & C. zalesskyi (1) & C. trifilievii (16) & C. beckii (6) & $\begin{array}{l}\text { Uniseriate, frequently biseriate in } \\
\text { part }\end{array}$ & Present & Frasnian \\
\hline $\begin{array}{l}\text { C. newberryi ( } 7 \text { cited } \\
\text { in } 12 \text { ) }\end{array}$ & $\begin{array}{l}\text { C. newberryi ( } 7 \text { cited } \\
\text { in } 15)\end{array}$ & $\begin{array}{l}\text { C. marshii (9) } \\
\text { C. mentethense (1) } \\
\text { C. schmidtii (11) }\end{array}$ & $\begin{array}{l}\text { C. schmidtii (11) } \\
\text { C. mentethense (1) }\end{array}$ & Uniseriate to pluriseriate & Present & Frasnian-Famennian \\
\hline C. $\operatorname{arnoldii}(4)$ & $\begin{array}{l}\text { C. kazakhstanum (13) } \\
\text { C. arnoldii (4) }\end{array}$ & & & $\begin{array}{l}\text { Uniseriate to pluriseriate } \\
\text { Uniseriate and biseriate }\end{array}$ & $\begin{array}{l}\text { Absent } \\
\text { Absent }\end{array}$ & $\begin{array}{l}\text { Frasnian } \\
\text { Upper Devonian-Lower } \\
\text { Mississippian }\end{array}$ \\
\hline
\end{tabular}

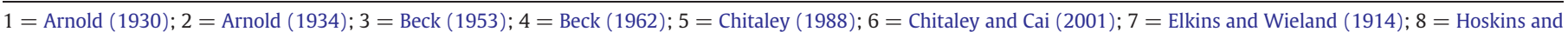

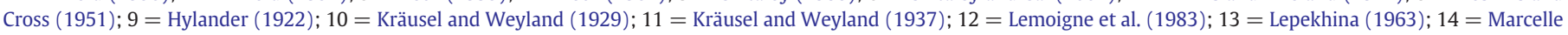
(1953); 15 = Orlova and Jurina (2011); 16 = Zalessky (1911). 
Givetian age of the latter locality was suggested in the protologue (Hylander, 1922), but has not been confirmed since then by any biostratigraphical data. Even more speculative is the report of a Callixylon-type of wood from the Givetian of Antarctica (Retallack, 1997). Based on the mid to late Givetian age of the Ronquières locality (Gerrienne et al., 2004; Ville de Goyet et al., 2007), the Callixylon specimen described here is therefore one of the earliest representatives of the genus.

Recent information obtained from a paleosol at Gilboa (New York State, USA) provides clear evidence for the existence, during midDevonian times, of mixed forests composed of arborescent lycopsids and cladoxylopsids, and of woody aneurophytalean progymnosperms (Stein et al., 2012). Based on the presence of characteristic stump casts and attached root systems in three other Givetian paleosols of the Manorkill Formation (New York State, USA), Mintz et al. (2010) suggested that forests inhabited by monospecific stands of arborescent Archaeopteridales occurred in the vicinity of the cladoxylopsid forests. According to these authors, those presumed archaeopterid forests grew in more upland positions and better drained environments than the cladoxylopsid forests which were established in deltaic and tidal-swamp environments (Mintz et al., 2010). The indirect evidence of tree-sized archaeopterids in the Givetian reported by Mintz et al. (2010) is corroborated by the specimen of Callixylon velinense mentioned above and the $12-15 \mathrm{~cm}$ wide Ronquières specimen described in this paper. Additional occurrences of Givetian archaeopterids from Belgium include two Stockmans' (1968) localities, namely the "Ronquières, tour du plan incliné (tête amont)" and the "Sart-Dame-Avelines" localities of Stockmans (1968), where archaeopteridalean fossils preserved as adpressions have been collected. These are assigned to Svalbardia, suggesting that the Givetian Callixylon from Belgium corresponded to archaeopterids with a Svalbardia type of leaves. In both localities, Svalbardia is found in association with the cladoxylopsids Wattieza and Pseudosporochnus (Stockmans, 1968; Berry, 2008). Archaeopterids and cladoxylopsids also co-occur at the outcrop where the Callixylon specimen described here was collected: cladoxylopsid specimens preserved as adpressions and as pyrite petrifactions were also found there (work in progress at Liege University). All the fossils at those Belgian localities are presumably allochthonous. Other Givetian archaeopteridalean remains (Archaeopteris and Svalbardia) from New York State are listed by Retallack and Huang (2011). Additional evidence of Givetian archaeopterids includes petrified axes of Actinoxylon from New York State (Matten, 1974), compressed specimens of Svalbardia from Scotland (Chaloner, 1972), southeastern Altay (Gutak et al., 2011), and Spitsbergen where they occur together with permineralized axes of Actinopodium (Høeg, 1942; Schweitzer, 1999). All this information indicates that the transition between the arborescent cladoxylopsid forests and the archaeopterid forests occurred during Givetian times, and that both types of vegetation presumably coexisted during several million years.

The Givetian occurrences of Archaeopteridales are plotted in Fig. 2. They are currently situated on the Laurussia palaeocontinent. Most Frasnian occurrences of Archaeopteridales are also provided (Meyer-Berthaud et al., 2004, and references therein; Hammond and Berry, 2005; Guo and Wang, 2011) in order to emphasize the spread of those plants during early Late Devonian times. Even though it might be an artifact due to a regional bias in the progymnosperm macrofossil record because of the lack of available localities on Gondwana, the configuration illustrated in Fig. 2 is suggestive of a center of early radiation of Archaeopteridales roughly located on Laurussia.

\section{Conclusion}

The mid to late Givetian Callixylon sp. from Ronquières represents one of the earliest occurrences of the genus. It is assigned to the "trifilievii

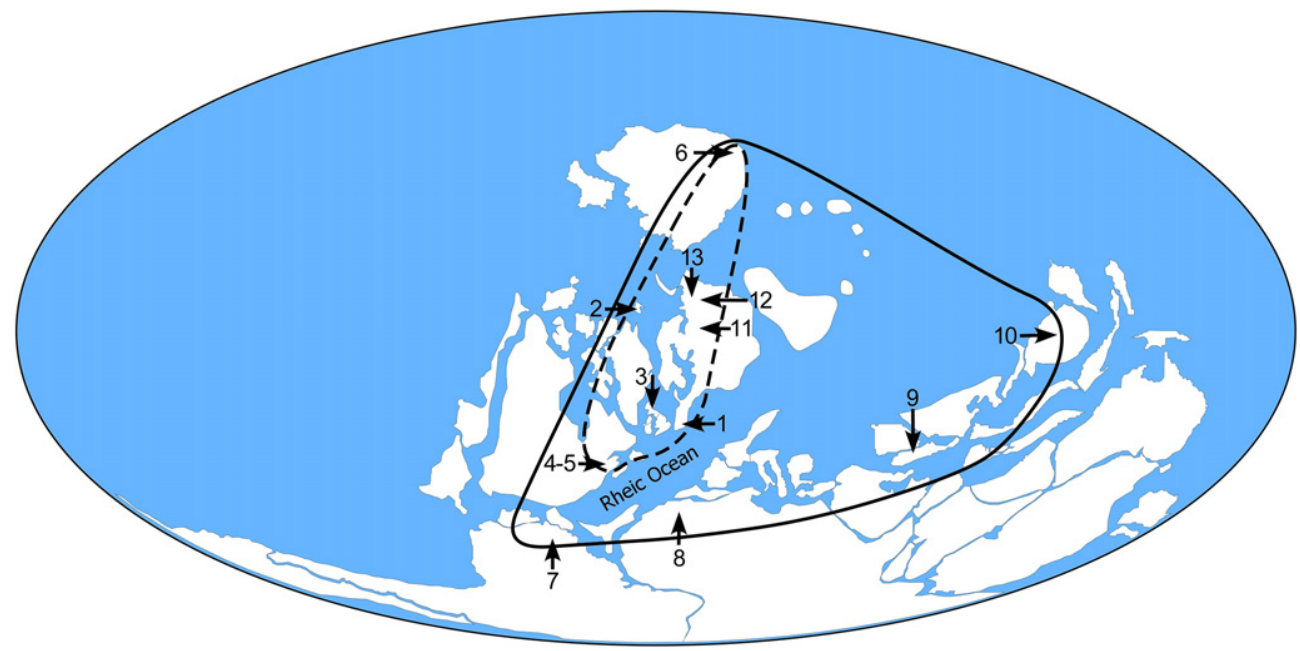

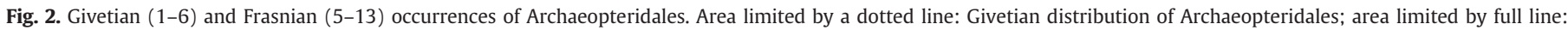
Frasnian distribution.

2. Spitsbergen: Svalbardia, Actinopodium (Høeg, 1942; Schweitzer, 1999).

3. Scotland: Svalbardia (Chaloner, 1972).

4. New York: Actinoxylon (Matten, 1974); stump cast of Archaeopteris (Mintz et al., 2010).

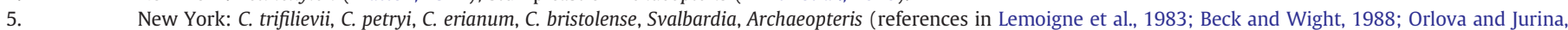

2011).

6. Southeastern Altay: Svalbardia, Archaeopteris (Gutak et al., 2011).

7. North West Venezuela, Campo Chico formation: Archaeopteris (Hammond and Berry, 2005).

8. Morocco, Anti-atlas: C. henkei (Meyer-Berthaud et al., 2004).

9. China, Xinjiang: C. clevelandensis (Chitaley and Cai, 2001).

10. China, Xinjiang: Archaeopteris (Cai, 1981; Hao and Mei, 1987; Guo and Wang, 2011).

11. Russia, Andonia mountain: Archaeopteris (Snigirevskaya and Snigirevsky, 2001).

12. Kazakhstan: C. kazakhstanum (Lepekhina, 1963; Orlova and Jurina, 2011).

13. Russia, North Timan: C. trifilievii (Zalessky, 1911; Orlova and Jurina, 2011).

Modified from Scotese (2002). 
group" circumscribed by Orlova and Jurina (2011). The discovery of this $12-15 \mathrm{~cm}$ wide Callixylon trunk at Ronquières confirms that the establishment of the tree habit in the lignophyte lineage occurred during Middle Devonian times. The coexistence at the locality of arborescent cladoxylopsids and of Callixylon remains also suggests that the early steps of the major floristic turnover between cladoxylopsid-populated and lignophyte-dominated forests were already perceptible during Givetian times, at least 15 million years before the world-wide dominance of Archaeopteris at the end of the Devonian Period.

\section{Acknowledgments}

The authors sincerely thank Marcela Mezzatesta-Giraldo and Joel Laval for their help in the preparation of the specimen. PG is a F.R.S.-FNRS Research Associate. AMAP (Botany and Computational Plant Architecture) is a joint research unit which associates CIRAD (UMR51), CNRS (UMR5120), INRA (UMR931), IRD (R123), and Montpellier 2 University (UM27); http://amap.cirad.fr/. This work is partly funded by the French National Agency for Research, project ANR No. 2010 BLAN 60702.

\section{References}

Allen, K.C., 1965. Lower and Middle Devonian spores of north and central Vestspitsbergen. Palaeontology 8, 687-748.

Arnold, C.A., 1929. On the radial pitting in Callixylon. American Journal of Botany 15 391-393.

Arnold, C.A., 1930. The genus Callixylon from the Upper Devonian of central and western New York. Papers of the Michigan Academy of Science, Arts and Letters 11, 1-50.

Arnold, C.A., 1934. Callixylon whiteanum sp. nov., from the Woodford chert of Oklahoma. Botanical Gazette 96, 180-185.

Balme, B.E., 1962. Upper Devonian (Frasnian) spores from the Carnarvon Basin, Western Australia. The Palaeobotanist 9, 1-10

Beck, C.B., 1953. A new root species of Callixylon (New York). American Journal of Botany 40, 226-233.

Beck, C.B., 1960. The identity of Archaeopteris and Callixylon. Brittonia 12, 351-368.

Beck, C.B., 1962. Plants from the New Albany Shale. II Callixylon arnoldii sp. nov. Brittonia 14, 322-327.

Beck, C.B., 1981. Archaeopteris and its role in vascular plant evolution. In: Niklas, KJ (Ed.), Paleobotany, Paleoecology, and Evolution. Praeger Publishers, New York, pp. 193-230.

Beck, C.B., Wight, D.C., 1988. Progymnosperms. In: Beck, C.B. (Ed.), Origin and Evolution of Gymnosperms. Columbia University Press, New York, pp. 1-84.

Becker, G., Bless, M.J., Streel, M., Thorez, J., 1974. Palynology and ostracode distribution in the Upper Devonian and basal Dinantian of Belgium and their dependence on sedimentary facies. Mededelingen Rijks Geologische Dienst, NS 25, 9-99.

Berry, C.M., 2008. The Middle Devonian plant collections of François Stockmans reconsidered. Geologica Belgica 12, 25-30.

Bultynck, P., Coen-Aubert, M., Dejonghe, L., Godefroid, J., Hance, L., Lacroix, D., Préat, A. Stainier, P., Steemans, P., Streel, M., Tourneur, F., 1991. Les formations du Dévonien moyen de la Belgique: Mémoire pour servir à l'explication des cartes géologiques et minières de Belgique, 30, pp. 1-105.

Cai, C.-Y., 1981. On the occurrence of Archaeopteris in China. Acta Palaeontologica Sinica 20, 75-78

Chaloner, W.G., 1972. Devonian plants from Fair Isle, Scotland. Review of Palaeobotany and Palynology 14, 49-61.

Chitaley, S., 1988. The wood Callixylon from the Late Devonian of Ohio, U.S.A. Review of Palaeobotany and Palynology 53, 349-357.

Chitaley, S., Cai, C.-Y., 2001. Permineralized Callixylon woods from the Late Devonian Cleveland Shale of Ohio, U.S.A. and that of Kettle Point, Ontario, Canada. Review of Palaeobotany and Palynology 114, 127-144.

Elkins, M.G., Wieland, G.R., 1914. Cordaitean wood from the Indiana Black shale. American Journal of Science 188, 68-78.

Fairon-Demaret, M., 1981. Le genre Leclercqia Banks, H. P., Bonamo, P. M. et Grierson, J. D., 1972 dans le Dévonien moyen de Belgique. Bulletin de l'Institut royal des Sciences naturelles de Belgique $53,10-13$.

Galtier, J., Phillips, T.L., 1999. The acetate peel technique. In: Jones, T.P., Rowe, N.P. (Eds.), Fossil Plants and Spores: Modern Techniques. Geological Society, London, pp. 67-70.

Gerrienne, P., Meyer-Berthaud, B., 2006. The permineralized lignophyte remains from Ronquières (Middle Devonian, Belgium): preliminary results. 7th European Palaeobotany-Palynology Conference, Prague (Czech Republic). Abstracts Volume. National Museum, Prague, pp. 46-47.

Gerrienne, P., Meyer-Berthaud, B., 2007. The proto-ovule Runcaria heinzelini Stockmans 1968 emend. Gerrienne et al., 2004 (mid-Givetian, Belgium): concept and epitypification. Review of Palaeobotany and Palynology 145, 321-323.

Gerrienne, P., Meyer-Berthaud, B. 2010. The secondary xylem of the putative early lignophyte Crossia (Stenokoleales) from Ronquières (Middle Devonian, Belgium). 8th European Palaeobotany Palynology Conference, 06-10/07/2010, Budapest, Hungary.

Gerrienne, P., Meyer-Berthaud, B., Fairon-Demaret, M., Streel, M., Steemans, P., 2004. Runcaria, a Middle Devonian seed plant precursor. Science 306, 856-858.

Guo, Y., Wang, D.-M., 2011. Anatomical reinvestigation of Archaeopteris macilenta from the Upper Devonian (Frasnian) of South China. Journal of Systematics and Evolution 49, 590-597.

Gutak, J.M., Antonova, V.A., Ruban, D.A., 2011. Diversity and richness of the Devonian terrestrial plants in the Southeastern mountainous Altay (Southern Siberia): regional versus global patterns. Palaeogeography, Palaeoclimatology, Palaeoecology 299, 240-249.

Hammond, S.E., Berry, C.M., 2005. A new species of Tetraxylopteris (Aneurophytales) from the Devonian of Venezuela. Botanical Journal of the Linnean Society 148, 275-303.

Hao, S.-G., Mei, S.-L., 1987. Further observations on Archaeopteris macilenta Lesquereux from western Hubei. Acta Palaeontologica Sinica 26, 555-562.

Hass, H., Rowe, N.P., 1999. Thin sections and wafering. In: Jones, T.P., Rowe, N.P. (Eds.), Fossil Plants and Spores: Modern Techniques. Geological Society, London, pp. 67-70.

Hennebert, M., Eggermont, B. 2002. Carte Braine-le-Comte-Feluy n 39/5-6, Carte géologique de Wallonie, échelle 1/25000. Direction Générale des Ressources Naturelles et de l'Environnement, Ministère de la Région Wallonne

Høeg, O.A., 1942. The Downtonian and Devonian flora of Spitsbergen. Norges Svalbard-og Ishavs-Unders, Skrifter 83, 1-228.

Hoskins, J.H., Cross, A.T., 1951. The petrification flora of the Devonian-Mississippian black shale. The American Midland Naturalist 23, 472-481.

Hylander, C.J., 1922. A Mid Devonian Callixylon. American Journal of Science 4, 315-321.

Kenrick, P., 1999. Opaque petrifaction techniques. In: Jones, T.P., Rowe, N.P. (Eds.), Fossil Plants and Spores: Modern Techniques. Geological Society, London, pp. 87-91.

Kräusel, R., Weyland, H., 1929. III Beiträge zur Kenntnis der Devonflora. Abhandlungen der Senckenbergischen - Naturforschenden Gesellschaft 7, 347-350.

Kräusel, R., Weyland, H., 1937. Pflanzenreste aus dem Devon. X. Zwei Pflanzenfunde im Oberdevon der Eifel. Senckenbergiana 19, 338-355.

Lemoigne, Y., Iurina, A., Snigirevskaya, N., 1983. Révision du genre Callixylon Zalessky 1911 (Archaeopteris) du Dévonien. Palaeontographica B 186, 81-120.

Lepekhina, V.G., 1963. New records of cordaitalean woods from the Upper Paleozoic of Kazakhstan. Paleontological Journal 4, 122-129.

Marcelle, H., 1953. Callixylon velinense nov. sp., un bois à structure conservée du Dévonien de la Belgique. Bulletin de la Société Géologique du Nord de la France 37, 908-919.

Matten, L.C., 1973. Preparation of pyritized plant petrifications. Review of Palaeobotany and Palynology 16, 165-173.

Matten, L.C., 1974. The Givetian flora from Cairo, New York: Rhacophyton, Triloboxylon and Cladoxylon. Botanical Journal of the Linnean Society 68, 303-318.

Meyer-Berthaud, B., Scheckler, S.E., Wendt, J., 1999. Archaeopteris is the earliest known modern tree. Nature 398, 700-704.

Meyer-Berthaud, B., Rücklin, M., Soria, A., Belka, Z., Lardeux, H., 2004. Frasnian plants from the Dra Valley, southern Anti-Atlas, Morocco. Geological Magazine 141, 675-686.

Mintz, J.S., Driese, S.G., White, J.D., 2010. Environmental and ecological variability of Middle Devonian (Givetian) forests in Appalachian basin paleosols, New York, United States. Palaios 25, 58-96.

Orlova, O.A., Jurina, A.L., 2011. Genus Callixylon Zalessky (Archaeopteridophyta): main criteria for distinguish its species and revision of its species composition. Paleontological Journal 45, 580-589.

Playford, G., 1971. Lower Carboniferous spores from the Bonaparte Gulf Basin, Western Australia and Northern Territory. Bulletin of the Bureau of Mineral Resources, Geology and Geophysics, Australia 115, 1-105.

Retallack, G.J., 1997. Early forest soils and their role in Devonian global change. Science 276, 583-585.

Retallack, G.J., Huang, C., 2011. Ecology and evolution of Devonian trees in New York, USA. Palaeogeography, Palaeoclimatology, Palaeoecology 299, 110-128.

Richardson, J.B., 1960. Spores from the Middle Old Red Sandstone of Cromarty, Scotland. Palaeontology 3, 45-63.

Richardson, J.B., 1962. Spores with bifurcate processes from the Middle Old Red Sandstone of Scotland. Palaeontology 5, 171-194.

Richardson, J.B., 1965. Middle Old Red Sandstone spore assemblages from the Orcadian Basin north-east Scotland. Palaeontology 7, 559-605.

Riegel, W., 1968. Die Mitteldevon Flora von Lindlar (Rheinland). 2. Sporae dispersae. Palaeontographica B 123, 76-96.

Scheckler, S.E., Banks, H.P., 1971. Anatomy and relationship of some Devonian progymnosperms from New York. American Journal of Botany 58, 737-751.

Scheckler, S.E., Skog, J.E., Banks, H.P., 2006. Langoxylon asterochlaenoideum Stockmans: anatomy and relationships of a fern-like plant from the Middle Devonian of Belgium. Review of Palaeobotany and Palynology 142, 193-217.

Schweitzer, H.-J. 1999. Die Devonfloren Spitzbergens. Palaeontographica B 252, 1-122.

Scotese, C.R., 2002. http://www.scotese.com (PALEOMAP website).

Snigirevskaya, N.S., Snigirevsky, S.M., 2001. New locality of Callixylon (Archaeopteridaceae) in the Late Devonian of Andoma Mountain (Vologda region, north-west Russia) and its importance for the reconstruction of archaeopterid distribution. Acta Palaeontologica Sinica 41, 97-105

Stein, W.E., Beck, C.B., 1983. Triloboxylon arnoldii from the Middle Devonian of western New York. Contributions from the Museum of Paleontology, University of Michigan 26, 257-288.

Stein, W.E., Berry, C.M., VanAller Hernick, L., Mannolini, F., 2012. Surprisingly complex community discovered in the mid-Devonian fossil forest at Gilboa. Nature 483, $78-81$. 
Stockmans, F., 1968. Végétaux mésodévoniens récoltés aux confins du massif du Brabant (Belgique). Institut Royal des Sciences Naturelles de Belgique, Mémoire, 159, pp. 1-49.

Stur, D., 1875. Beiträge zur Kenntniss der Flora der Vorwelt. Band I. Die Culm-Flora des mährisch- schlesischen Dachschiefer. Abhandlungen der Kaiserlich-Königlichen Geologischen Reichsanstalt 8, 1-106.

Taylor, T.N., Taylor, E.L., Krings, M., 2009. Paleobotany, the Biology and Evolution of Fossil Plants, Second Edition. Academic Press, Elsevier. 1230 pp.
Ville de Goyet, F., Breuer, P., Gerrienne, P., Prestianni, C., Streel, M., Steemans, P., 2007. Middle Devonian (Givetian) megaspores from Belgium (Ronquières) and Libya (A1-69 borehole). Carnets de Géologie/Notebooks on Geology, Memoir 2007/01, abstract 11 (CG 2007_M01/11).

Wang, Q., 2011. Correct author citation of the Late Devonian plant Archaeopteris (Progymnospermopsida). Paleontological Journal 45, 347-349.

Zalessky, M.D., 1911. Etude sur l'anatomie du Dadoxylon tchihatcheffi Goeppert sp. Mémoire du Comité Géologique de Russie, 68, pp. 1-29. 